\title{
Pengaturan Perpajakan Daerah Dalam Sistem Hukum Pajak Indonesia
}

\author{
Mustaqiem
}

Abstrak

Based on Statutes and regulatiuon above, the enacttment of local taxation were decentralization pattem, even though both the systems are use the same time. The local regulation have function as legal base for imposition the local tax, to fulfill the formal and materiil standart that have been determined by laww and regulation upon him.

\section{Pendahuluan}

Guna melaksanakan pemerintahan di setiap negara diperlukan berbagai macam dana pendukung sebab tanpa dukungan dana yang mencukupi program kegiatan pemerintah tidak dapat direalisir optimal. Dana yang diperlukan dalam penyelenggaraan pemerintahan tidak sedikit, sehingga memerlukan banyak sumber-sumber penerimaan dana, apalagi disertai dengan kegiatan pembangunan.' Penerimaan Pemerintah mempunyai arti yang luas, meliputi : pajak, hasil penjualan barang dan jasa, pinjaman, mencetak uang, dan sebagainya. ${ }^{2}$ Pendapat lain mengatakan bahwa penerimaan negara berasal dari :

(a) pungutan (b) pinjaman,

(c) penciptaan uang baru.

Pungutan sendiri merupakan nama himpunan yang meliputi pajak, retribusi, sumbangan, monopoli, dan pungutanpungutan lain. Khusus penerimaan dari sektor pajak, eksistensinya pada dasarnya sebagai species dan genus pemungutan telah ada sejak zaman Romawi. ${ }^{3}$

Beberapa penerimaan pemerintah tersebut, jika disederhanakan dapat dibedakan atas penerimaan pajak dan penerimaan non-pajak. ${ }^{4}$ Pajak sebagai salah satu penerimaan pemerintah, dapat dikatagorikan sebagai berikut: ${ }^{\mathbf{5}}$

a). State taxes:

(1) Income tax;

(2) Value-added tax;

'Arifin P. Soeria Atmadja, Mekanisme Pertanggungjawaban Keuangan Negara Suatu Tinjauan Yuridis, Gramedia, Jakarta, 1986, hilm. 3

2Suparmoko, Keuangan Negara, BPFE, Yogyakarta, 1999, hlm,93-94.

${ }^{3}$ Santoso Brotodihardjo, Pengantar IImu Hukum Pajak, Fresco, Bandung, 1989, hirn.2

${ }^{4}$ Tomo,HS, dkk; Penerimaan Negara Bukan Pajak, 'YIAPI, Yogyakarta, 2004, hlm. 16.

${ }^{5}$ Doing Busness and Investing in Indonesia, Price Vaterhouse Cooper, 1994,p. 129 
(3) Sales tax on luxury goods;

(4) Stamp tax;

(5) Property tax (on land and buildings);

(6) Fiscal exit tax.

b). Regional taxes:

(1) Development tax;

(2) Motor vehicles tax;

(3) Other minor taxes, including household tax.

c). Customs and excise taxes:

(1) Export tax;

(2) Import tax;

(3) Tobacco, sugar, beer and alcohol and gasoline taxes.

Pemungutan pajak di Indonesia secara yuridis konstitusional awalnya didasarkan pada Pasal 23 ayat (2) Undang-Undang Dasar 1945 yang menetapkan bahwa, segala pajak untuk negara berdasar undang-undang. Selanjutnya pasal tersebut diamandemen dengan Pasal 23 A Undang-Undang Dasar 1945 yang menetapkan : "pajak dan pungutan lain yang sifatnya memaksa untuk keperluan negara diatur dengan undang-undang". Pasal hasil amandemen tersebut cakupannya lebih luas jika dibandingkan dengan pasal sebelumnya. Maksudnya ialah pasal hasil amandemen selain sebagai dasar pemungutan pajak, juga sekaligus sebagai dasar pungutan lain di luar pajak yang sifatnya memaksa.

Berkaitan dengan kategori pajak, mulai tahun 1957 sampai sekarang di Indonesia terdapat pajak pusat dan pajak daerah. Terciptanya kategori pajak tersebut, tidak lepas dari bentuk Indonesia sebagai negara kesatuan, yang wilayahnya terdiri atas berbagal daerah; seperti yang ditetapkan dalam Pasal 18 Undang-Undang Dasar 1945 ayat (1) "Negara Kesatuan Republik Indonesia dibagi atas daerah-daerah Provinsi dan daerah Provinsi itu dibagi atas Kabupaten dan Kota, yang tiap-tiap Provinsi, Kabupaten, dan Kota itu mempunyal pemerintahan daerah, yang diatur dengan undang-undang".

Berdasarkan peraturan perundangundangan yang dipergunakan untuk mengatur Pemerintahan Daerah yang pernah berlaku selama ini, memposisikan Pemerintah Daerah berstatus sebagai Daerah Otonom. Konsekuensi Daerah Otonom adalah harus memiliki sumber pendapatan asli daerah sendiri, yang salah satunya berasal dari hasil pajak daerah.

Selama perjaianan waktu, peraturan perundang-undangan yang dipakai untuk mengatur pajak daerah meliputi :

(a). Undang Undang Nomor 11 I Drt / 1957, (b). Undang Undang Nomor 18 Tahun 1997, (c). Undang Undang Nomor 34 Tahun 1999. Keberadaan peraturan perundang-undangan tersebut, tidak lepas dari peraturan perundang-undangan yang mengatur tentang Pernerintahan Daerah; seperti Undang Undang Nomor 1 Tahun 1957, Undang Undang Nomor 5 Tahun 1974, Undang Undang Nomor 22 Tahun 1999, maupun Undang Undang Namor 32 Tahun 2004.

Berdasarkan latar belakang permasalahan di atas, maka tulisan ini akan mengkaji; pertama, bagaimana pengaturan perpajakan daerah dalam sistem hukum pajak Indonesia? Kedua, bagaimana kriteria produk hukum pajak daerah dalam sistem hukum pajak Indonesia?

\section{Sistem Perpajakan}

Secara singkat sejarah pemungutan pajak pada umumnya dapat digambarkan 
mulai zaman purba. ${ }^{6}$ Pada zaman purba itu, orang menganggap sangat bijaksana dan berbudi luhur untuk secara sukarela turut serta memelihara kelangsungan kehidupan negaranya. Hal tersebut diawali apabila pengeluaran-pengeluaran para raja pada waktu itu sudah tidak dapat ditutup dengan penghasilan pribadinya, kemudian berubah disampaikan suatu permintaan kepada rakyat akan sumbangan berupa barang atau uang. Permintaan raja seperti itu dalam bahasa Belanda disebut "bede". 7 Lambat-faun, sifat permintaan itu berubah menjadi suatu paksaan, proses sifat paksaan tersebut dimulai setelah kerajaan-kerajaan memperluas wilayahnya dengan cara menundukkan sukusuku bangsa lain. rakyat suatu daerah yang sudah dapat ditundukkan tanpa ada paksaan tidak akan memberikan sumbangan untuk memelihara kelangsungan hidup negara. Pada perubahan yang terjadi dalam masyarakat, pemungutan pajak secara paksaan atau sewenang-wenang sudah tidak diperlukan lagi, karena dalam masyarakat modern kehidupan memerlukan pedoman yang berupa aturan hukum. Berkenaan dengan hal tersebut, pemunguran pajak saat sekarang harus didasarkan atas asas-asas dan norma-norma hukum. ${ }^{8}$ Selain itu, masih harus memperhatikan juga hal-hal yang berkaitan dengan : (1). Keadilan, dalam arti pemungutan pajak harus bersifat umum, merata dan menurut kekuatan,
(2). Ekonomi, bahwa pemungutan pajak tidak akan merusak sumber-sumber kemakmuran rakyat, (3). Dapat mencapai tujuan, bahwa pemungutan pajak jangan sampai mengakibatkan adanya kemungkinan penyelundupan atau pengurangan hasil karena tarifnya terlalu tinggi. ${ }^{9}$ Sebenarnya bagi rakyat indonesia, istilah pajak seperti yang dikenal sekarang ini bukan merupakan istilah asing, karena istilah tersebut sudah menjadi istilah sehari-hari; bahkan mengenai pemungutan pajak sudah dikenal oleh rakyat Indonesia jauh sebelum abad $17 . .^{10}$

Berkaitan dengan pajak, dalam literatur dapat ditemukan berbagai definisi pajak. Berdasarkan pendapat yang ada, pada garis bèsarnya pajak merupakan iuran rakyat pada kas negara berdasarkan undang-undang (dapat dipaksakan secara yuridis) dengan tidak mendapatkan jasa balik (kontraprestasi) yang langsung dapat ditujukan dan yang digunakan untuk membayar pengeluaran umum. ${ }^{11}$ Sedang pengertian hukum pajak, adalah keseluruhan peraturan-peraturan yang meliputi wewenang pemerintah untuk mengambil kekayaan seseorang dan menyerahkannya kembali kepada masyarakat melalui kas negara, sehingga ini (hukum pajak) merupakan bagian dari hukum publik yang mengatur hubungan hukum antara negara (sebagai pemungut pajak) dengan masyarakat (sebagai pembayar pajak). ${ }^{12}$ Pendapat lain memberikan pengertian

\footnotetext{
${ }^{6}$ Soedargo, Pajak Daerah dan Retribusi Daerah, Eresco, Bandung, 1964, hlm. 2

${ }^{7}$ lbid.

${ }^{8} \mathrm{lbid}$.

${ }^{9} \mathrm{lbid}$.

${ }^{10}$ Chidir Ali, Hukum Pajak, Eresco, Bandung, 1993, hlm. 24

"Mardiasmo, Perpajakan, Andi, Yogyakarta, 2000, him. 1

${ }^{12}$ Santoso Brotodihardjo, Pengantar ..., op.cit., hlm. 1
} 
tentang hukum pajak, sebagai suatu kumpulan peraturan-peraturann yang mengatur hubungan antara pemerintah sebagai pemungut pajak dan rakyat sebagai pembayar pajak. ${ }^{13}$ -

Berdasarkan kewenangan pemungutannya, pajak dapat dibedakan menjadi pajak pusat (pajak yang pemungutannya berdasarkan undang-undang dan hasil pajak dipergunakan untuk membiayai rumah tangga negara) dan pajak daerah (pajak yang pemungutannya berdasarkan Peraturan daerah dan hasil pajak daerah dipergunakan untuk kepentingan penyelenggaraan rumah tangga daerah, sebagai badan hukum publik). ${ }^{14}$

Menurut berbagai teori terdapat dasar pembenaran negara memungut pajak. Dasar pembenar tersebut adalah :

(1). Teori asuransi,

(2). Teori kepentingan,

(3). Teori bakti,

(4). Teori daya beli,

(5). Teori daya pikul.

Di Indonesia yang dapat dipergunakan sebagai landasan filosofis pemungutan pajak, adalah Pembukaan UUD 1945 alenia IV dan Pasal 23 A UUD 1945. Tujuan negara yang termaktub dalam alenia IV UUD 1945 harus diwujudkan. Guna mewujudkan tujuan negara, diperlukan dukungan dana yang tidak sedikit, dan salah satu upaya untuk memenuhi kebutuhan dana dilakukan pemungutan pajak. Pembayaran pajak yang dilakukan oleh rakyat merupakan hak rakyat kepada negara.

\section{Keuangan Negara}

Negara yang didirikan oleh sekelompok orang pada dasarnya merupakan awal untuk melangkah lebih lanjut, karena langkah berikut yang harus dilakukan masih banyak ragamnya; satu diantaranya adalah mewujudkan tujuan negara yang sudah menjadi kesepakatan bersama. Semua tujuan negara adalah sama, karena untuk penciptaan kesejahteraan bagi rakyatnya. ${ }^{15}$ Selain itu tujuan negara yang demokratis, adalah mempertinggi kemakmuan rakyat. ${ }^{16}$ Tujuan negara merupakan kepentingan bersama seluruh rakyat, sehingga biaya-biaya yang harus dikeluarkan untuk merealisasi program-program negara menjadi tanggungjawab bersama pula. Untuk menutup pengeluaran negara dalam rangka mereaalisasi programprogramnya, negara mencari pembiayaan dengan cara menarik pajak. Tidak berlebihan jika pajak dipergunakan sebagai unsur pembiayaan negara. ${ }^{17}$ Sehingga pemungutan pajak merupakan hal yang harus dilakukan oleh negara sebagai suatu fungsi esensial, artinya hasil pelaksanaan fungsi itu dapat dijadikan alat penggerak kegiatan, baik untuk kegiatan fungsi esensial itu sendiri maupun fungsi jasa dan niaga.

Bagi suatu negara masalah keuangan negara sangat penting, makin baik keuangan negara makin stabil pula kedudukan pemerintahan dalam negara itu, sebaliknya jika keuangan negara kacau maka pemerintah akan menghadapi berbagai kesulitan dan

\footnotetext{
${ }^{13}$ Rahmat Soemitro, Dasar-DasarHukum Pajak dan PajakPendapatan 1944, Eresco, Bandung 1979, hlm. 24 ${ }^{14}$ Soedargo, loc.cit, hlm. 11

${ }^{15}$ Chidir Ali, Loc.cit, hlm. 13

${ }^{16}$ AJ. Wisse, Keuangan Negara, Jajasan Pembangunan, Djakarta, 1950, h/m. 11

${ }^{17}$ G. Goedhart, Garis-Garis Besar Ilmu Keuangan Negara, (terjemahan), Djambatan, Djakarta, 1975, hlm. 131
} 
rintangan dalam penyelenggaraan segala kewajiban yang diberikan kepadanya. Demikian pula bagi Pemerintah Daerah, keuangan daerah merupakan masalah yang sangat penting baginya untuk mengatur dan mengurus masalah rumah tangganya sendiri. $^{18}$

\section{Sumber Pendapatan Pemerintah Daerah}

Sumber pendapatan daerah, berasal dari berbagai sektor, salah satunya berasal dari pajak daerah. Pendapatan dari sektor pajak daerah, dapat dibedakan menjadi tiga: (1) Berasal dari pembagian hasil pajak-pajak yang dikenakan atau dipungut oleh pemerintah pusat, (2) Berasal dari pungutan tambahan (opsen) atas suatu pajak yang dipungut atau dikumpulkan oleh pemerintah pusat, (3) Berasal dari pajak yang diatur dan dikumpulkan oleh pemerintah daerah sendiri. ${ }^{19}$ Pajak yang dipungut pemerintah daerah, dapat ditetapkan berdasarkan ketentuan peraturan perundang-undangan pemerintah pusat, yang bisa bersifat memerintah atau mengijinkan atau dengan istilah lain pemerintah pusat dapat memerintahkan pemerintah daerah untuk memungutnya, atau semata-mata memberikan wewenang untuk melaksanakan. Pendapat lain mengatakan, bahwa suatu jenis pajak bukan merupakan pajak "regional/ daerah" kecuali apabila pajak tersebut dikenakan berdasarkan peraturan perundangundangan regional/daerah bukan berdasar ketentuan nasional. ${ }^{20}$ Pihak lain berpendapat, bahwa pengendalian tarif oleh daerah-daerah dipakai sebagai tolok ukurnya. Dalam hal kecermatan semantik/hukum, penilaian definisi tidak merupakan hal yang sangat penting, namun demikian,- hal tersebut merupakan makna yang lebih penting jika dianggap bahwa perpajakan yang didasarkan perundang-undangan pemerintah regionall daerah membawa akibat kewenangan yang lebih luas dan kebebasan berkarya dalam arti keuangan lebih leluasa.

Selain itu, perpajakan daerah dapat diartikan bermacam-macam, yaitu :

(1) Pajak yang dipungut oleh pemerintah daerah dengan pengaturan dari daerah sendiri,

(2) Pajak yang dipungut berdasarkan peraturan nasional tetapi penetapan tarif pajak dilakukan oleh pemerintah daerah,

(3) Pajak yang ditetapkan dan/atau dipungut oleh pemerintah daerah,

(4) Pajak yang dipungut dan diadministrasikan oleh pemerintah pusat, tetapi hasil pungutannya diberikan, dibagi hasilkan dengan/atau dibebani pungutan tambahan opsen oleh pemerintah daerah. ${ }^{21}$ Suatu sumber pajak menjadi menarik, apabila pemerintah daerah memperoleh pendapatan dari sumber tersebut; apakah memungut atau mengadministrasikan atau tidak, atau menetapkan tarifnya. Sebenarnya banyak cara untuk meningkatkan penghasilan dari pajak, tetapi kebanyakan pemerintah Propinsi

\footnotetext{
${ }^{18}$ M. Manullah, Dasar-Dasar Manajemen, Medan, 1974, hlm. 12

${ }^{19}$ KJ. Davey, Pembiayaan Pemerintah Daerah, Ul Press, Jakarta, 1988, hlm. $28-29$

$20 \mathrm{bid}$.

21 lbid.
} 
dan Kota/Kabupaten masih banyak yang menggantungkan bantuan dari anggaran pemerintah pusat. ${ }^{22} \mathrm{Hal}$ tersebut terjadi, karena pemerintah pusat terlalu dominan terhadap daerah. Pola pendekatan yang sentralistik dan seragam yang selama ini dikembangkan oleh pemerintah pusat telah mematikan inisiatif dan kreatifitas daerah. ${ }^{23}$ Meskipun pemerintah memiliki kewenangan menetapkan perpajakan daerah. Tetapi kelayakan pajak perlu diperhatikan. Beberapa pertimbangan yang harus diperhatikan untuk menilai pajak daerah layak atau tidak, ialah:

(1). Tax yeild,

(2). Equity,

(3). Economic efficiency,

(4). Ability to Implement,

(5) Suitability as a local revenue source.

\section{Sistem Hukum Pajak Indonesia}

Berbicara mengenai sistem hukum nasional akan ditemukan beberapa macam pendapat tentang hal ini, seperti yang dikutip Abdurrahman berikut ini. ${ }^{24}$

(1) Sistem hukum nasional, segala hukum yang berlaku secara nasional dan sah diseluruh tanah air dari Sabang sampai Merauke (dari Banda Aceh sampai dengan Irian Jaya / Papua), yang dibuat oleh badanbadan atau lembaga-lembaga nasional yang, berwenang (JCT Simorangkir).

(2) Șistem hukum nasional, tata hukum baru yang lahir sebagai akibat dan kemerdekaan bangsa Indonesia dengan Undang-Undang Dasar 1945 sebagai intinya (Satjipto Rahardjo).

(3) Hukurn nasional (national law), "has two connotation: one meaning axacly, national in contrast with the local the other more prevalent during the last two decades meaning the law of independent Indonesian as opposed to law originating in the colony" (Daniel S. Lev).

(4) Hukurn nasional, ialah :

(a) hukum yang dinyatakan berlaku secara nasional oleh pembentuk undangundang nasional,

(b). hukum yang bersumber dan menjadi pernyataan langsung dan tata budaya nasional,

(c). hukum yang bahan-bahannya (idiil dan riil) primair berasal dari kebudayaan nasional sendiri dengan tidak menutup kemungkinan memasukkan bahan-bahan dari luar sebagai hasil pengolahan yang dibawa oleh perhubungan dengan luar nasional,

(d). sebagal pengertian politis perlawanan antara nasional dan kolonial (Moh. Koesnoe).

Berpedoman pada sistem hukum nasional tersebut, maka pengertian sistem hukum pajak Indonesia tidak akan jauh berbeda karena secara konstitusional kewajban negara membuat hukum pajak sudah ditetapkan melalui Pasal 23 A Undang-Undang Dasar 1945. Sehubungan

${ }^{22}$ Richard L. Siegel, at all, Comparing Public Policy-United State-Soviet Union and Europe, The Dorsey Press, Homewood Illinois 60430 Irwin Dorsey Limited Georgetown, Ontario, p. 289.

${ }^{23}$ Mardiasmo, Otonomi dan Manajemen Keuangan Daerah, Andi, Yogyakarta, 2002, hlm. 96

${ }^{24}$ Abdurrahman, BeberapaAspek Tentang Pembangunan Hukum Nasional, Citra Aditya Bakti, Bandung, 1995, hlm,145-149. 
dengan hal tersebut, yang dimaksud dengan sistem hukum pajak Indonesia ialah sistem hukum dibidang perpajakan yang dibuat menurut ketentuan Undang-Undang Dasar 1945 maupun peraturan perundang-undanigan lain yang dipergunakan sebagai dasar hukum pengaturan bidang perpajakan di Indonesia.

Pengaturan perpajakan daerah di Indonesia selama ini berpedoman pada dua kaedah jalah kaedah sentral (central norm) maupun kaedah local (local norm). Kaedah sentral (central norm) dalam pengaturan perpajakan daerah dapat dibedakan menjadi dua, ialah:

(1) Peraturàn perundang-undangan pemerintahan daerah, rnelipuli

a). Undang-Undang Nomor I Tahun 1957.

b): Undang-Undang Nomor 5 Tahun 1974.

c). Undang-Undang Nomor 22 Tahun 1999.

d). Undang-Undang Nomor 32 Tahun 2004.

(2) Peraturan perundang-undangan pajak dan retribusi daerah, meliputi

a). Undang Undang Nomor 11 / Drt/1957. b). Undang Undang Nomor 18 Tahun 1997. c). Undang Undang Nomor 34 Tahun 2000. Kaedah lokal (local norm) dalam pengaturan perpajakan daerah menggunakan Peraturan Daerah yang dibuat dan diberlakukan oleh Pemerintah Daerah yang bersangkutan.

Substansi peraturan perundang-undangan pajak daerah dan retribusi daerah tidak dapat lepas dari pengaruh karakter peraturan perundang-undangan pemerintahan daerah. Seperti pendapat Moh. Mahfud, konfigurasi politik tertentu menyebabkan lahirnya produk hukum dengan karakter tertentu pula.
Berdasarkan pendapat tersebut dan didukung dengan pendekatan yuridis-historis, maka pengaturan perpajakan daerah yang pernah atau sedang dijalankan adalah sebagai berikut:

Tabel 1

\begin{tabular}{|c|c|c|c|}
\hline 1 & $\begin{array}{l}\text { Masa UU } \\
\text { No.11/ Drt / } \\
1957 . \\
\text { UU No.1 } \\
\text { Tahun } 1957 . \\
\end{array}$ & $\begin{array}{l}\text { DPR berhak meng- } \\
\text { adakan pajak dan } \\
\text { retribusi daerah } \\
\text { (Desentralistik) }\end{array}$ & Domokratis \\
\hline 2 & $\begin{array}{l}\text { Masa UU No. } \\
18 \text { Tahun } \\
1997 . \\
\text { UU No. } 5 \\
\text { Tahun } 1974 .\end{array}$ & $\begin{array}{l}\text { Pajak dan Retribusi } \\
\text { Daerah. ditetapkan } \\
\text { oleh pemerintah } \\
\text { (Sentralistik) }\end{array}$ & Otoriter \\
\hline 3 & \begin{tabular}{|l|} 
Masa UU No. \\
34 Tahun \\
2000.
\end{tabular} & \begin{tabular}{|l|} 
Pajak dan Retribusi \\
Daerah ditetapkan \\
p e m e i I n t a h \\
( Se n t $r$ a lis tik $)$ \\
Kabupaten / Kota \\
dengan Perda oleh \\
menetapkan jenis \\
pajak daerah, di luar \\
yang sudah ditetapkan \\
p e m e r i n t a h . \\
(Desentralistik)
\end{tabular} & $\begin{array}{l}\text { Otoriterdan } \\
\text { Demokratis }\end{array}$ \\
\hline 4 & $\begin{array}{l}\text { UU No. } 22 \\
\text { Tahun } 1999 \text {. } \\
\text { Masa UU No. } \\
34 \text { Tahun } \\
2000 . \\
\text { UU No. } 32 \\
\text { Tahun } 2004 .\end{array}$ & $\begin{array}{l}\text { Pajak dan Retribusi } \\
\text { Daerah ditetapkan } \\
\text { p e m e r i n t a h } \\
\text { ( S entra lis tik) } \\
\text { Kabupaten / Kota } \\
\text { dengan perda boleh } \\
\text { menetapkan jenis } \\
\text { Pajak daerah, di luar } \\
\text { yang sudah ditetapkan } \\
\text { p e m e r.i n t a h } \\
\text { (Desentralistik). }\end{array}$ & $\begin{array}{l}\text { Otonititerdan } \\
\text { Demokratis }\end{array}$ \\
\hline
\end{tabular}

\section{Kriteria Produk Hukum Pajak Daerah dalam Sistem Hukum Pajak Indonesia}

Pengertian hukum pada dasarnya dapat ditafsirkan secara terbatas ialah sebagai keputusan. ${ }^{25}$ Di Indonesia, hukum pajak

${ }^{25}$ Yudha Bakti Ardhiwisastra, Penafsiran dan Konstruksi Hukum, Alumni, Bandung, 2000, hlm.6 
merupakan juga keputusan pengusaha; hal ini didasarkan atas Pasal 23 A Undang-Undang Dasar 1945. Menurut Kusumadi Pudjosewojo, nama lain hukum pajak adalah hukum fiskal. ${ }^{26}$ Pendapat Rochmat Soemitro, hukum pajak adalah suatu kumpulan peraturan-peraturan yang mengatur hubungan antara pemerintah sebagai pemungut pajak dan rakyat sebagai pembayar pajak. ${ }^{27}$ Lain perkataan, hukum pajak menerangkan : Siapa-siapa wajib pajak (subyek) dan apa kewajiban-kewajiban mereka terhadap pemerintah, hak-hak pemerintah, obyek apa yang dikenakan pajak, timbul dan hapusnya hutang pajak, cara penagihan, cara mengajukan keberatan-keberatan, dan sebagainya. ${ }^{28}$ Menurut Hans Kelsen, bahwa norma-norma hukum itu berjenjang-jenjang dan berlapis-lapis dalam suatu hirarki tata susunan norma yang lebih rendah berlakunya sampai dengän norma dasar (ground norm). ${ }^{29}$ Selain itu, menurut teori perundang-undangan, pembentukan peraturan perundang-undangan meliputi dua masalah pokok yang harus diperlihatkan, ialah aspek materiil/substansial dan aspek formil/prosedural..$^{30}$ Aspek materiil/ substansial berkenaan dengan ini dari suatu peraturan perundang-undangan, sedang aspek formil/prosedur berkaitan dengan kewenangan dan tahapan pembuatannya. berdasarkan pendapat tersebut, menunjukkan bahwa dalam pembentukan produk hukum pajak daerah atau kaedah lokal (local norm) yang berbentuk peraturan Daerah Nomor 1 Tahun 2002 di Propinsi Daerah Istimewa Yogyakarta, telah memenuhi dua hal, ialah : (1). Aspek formil, (2) Aspek rnateriil. Pemenuhan terhadap dua aspek tersebut dapat dijelaskan sebagal berikut::

1). Pemenuhan Aspek Formil (procedural).

(a). UU Nomor: 22 Tahun 1999, Pasal 69 "Kepala Daerah menetapkan Perda atas persetujuan DPRD dalam rangka penyelenggaraan otonomi daerah dan penjabaran lebih lanjut dan peraturan perundang-undangan yang lebih tinggi"

(b) UU Nomor: 32 Tahun 2004, Pasal 136 ayat (1): "Perda ditetapkan oleh Kepala Daerah setelah mendapatkan persetujuan bersama DPRD

2). Pemenuhan Aspek Materiil (substans).

(a). UU Nomor: 22 Tahun 1999, Pasal 70: "Perda tidak boleh bertentangan dengan kepentingan urnum, Perda lain, dan peraturan perundangundangan yang tebih tinggi.

(b). UU Nomor: 32 Tahun 2004, Pasal 136 ayat (4): "Perda dilarang bertentangan dengan kepentingan umum, danl atau peraturan perundang-undangan yang lebih tinggi".

(c) UU Nomor 10 Tahun 2004, Pasal 12:

\footnotetext{
${ }^{26}$ Kusumadi Pudjosewojo, Pedoman Pelajaran tata Hukum Indonesia, Aksara Baru, Jakarta, 1986, hlm. 177

${ }^{27}$ Rochmat Soemitro, Dasar-DasarPerpajakan Dan Pajak Pendapatan 1944, Eresco, Jakarta-Bandung, 1979, hlm. 24

${ }^{28} \mathrm{lbid}$, him. 24-25

${ }^{29}$ Hans Kelsen, General Theory of Law and State , alih bahasa oleh Somadi berjudul: Teoeri Hukum Mumi (dasar-dasar ilmu hukum normative sebagai ilmu hukum empiric-descreptif), Rindi, Pres, Jakarta, 1995, hlm. 16

${ }^{30}$ Laboratorium Hukum Fakultas Hukum Universitas Katholik Parahyangan, Ketrampilan Perancangan Hukum, Citra Aditya Bakti, Bandung, 1997, h/m. 2
} 
Materi muatan Perda adalah seluruh materi muatan dalam rangka penyelenggaraan otonomi daerah dan tugas pembantuan, dan menampung kondisi khusus daerah, serta penjabaran lebih lanjut peraturan perundang-undangan yang lebih tinggi.

(d) UU. Nomor: 34 Tahun 2000:

Pasal 2:

(1) Jenis pajak Provinsi terdiri dari : Pajak Kendaraan Bermotor, Bea Balik Nama Kendaraan Bermotor Pajak Bahan Bakar Kendaraan Bermotor, Pajak Pengambilan dan Pemanfaatan Air Bawah Tanah dan Air Permukaan.

(2) Jenis pajak Kabupaten/Kota terdiri daril Pajak Hotel, Pajak Restoran, Pajak Hliburan, Pajak Reklame Pajak Penerangan Jalan, Pajak Pengambilan Bahan Galian Golongan C, Pajak Parkir.

Pasal 3:

(1) "Maksimal tarif pajak daerah ditetapkan paling tinggi sebesar...." (sentralistik).

(2) Tarif pajak daerah (Provinsi) ditetapkan seragam diseluruh Indonesia dan diatur dengan Peraturan Pemerintah (sentralistik).

(3) Tarif pajak daerah (Kabupaten I Kota) ditetapkan dengan Peraturan Daerah (desentralistik).

\section{Simpulan}

Berdasarkan pendekatan yuridis-histories, pengaturan bidang perpajakan daerah di Indonesia dapat dibedakan menjadi 4 (empat) sistem, ialah : (a). Mempergunakan sistem desentralistik pada waktu otonomi seluas-luasnya.

(b). Mempergunakan sistem sentralistik pada waktu otonomi nyata dan bertanggungjawab.

(c). Mempergunakan sistem sentralistlk dan desentralistik pada waktu otonomi luas, nyata dan bertanggungjawan.

(d). Menggunakan sistem sentralistik dan desentralistik pada waktu otonomi seluasluasnya.

Produk hukum yang berbentuk Peraturan Daerah Nomor 1 Tahun 2002 Tentang Pajak Daerah Propinsi Daerah Istimewa Yogyakarta, telah memenuhi kriteria produk hukum dalam sistem hukum pajak nasional, karena telah memenuhi ketentuan formil dan materiil.

Menurut ketentuan formil, pembuatan Peraturan Daerah tersebut harus melibatkan dua lembaga daerah (eksekutif dan legislatif), seperti yang diatur dalam Undang Undang Nomor 22 Tahun 1999 Pasal 69: maupun Undang Undang Nomor 32 Tahun 2004, Pasal $25 \mathrm{C}$, jika diukur dengan ketentuan materiil, menunjukkan bahwa Peraturan Daerah tersebut telah memenuhi ketentuan dalam Undang-Undang Nornor 22 Tahun 1999, Pasal 70; Undang-Undang Nomor 34 Tahun 2000, Pasal 2 ayat (1) dan (2), dan Pasal 4 ayat (3); Undang-Undang Nomor 32 Tahun 2004, Pasal 136 ayat (4); Undang Undang Nomor 10 Tahun 2004, Pasal 12.

Berdasarkan hal tersebut, mengindikasikan bahwa sepanjang pengaturan bidang perpajakan daerah tetap menggunakan sistem sentralistik, maka ketentuan formil dan materiil tetap diberlakukan. Tetapi sebaliknya, apabila pengaturan bidang perpajakan daerah menggunakan sistem desentralistik, maka yang tetap diberlakukan hanya ketentuan formil, sedang ketentuan materiil tidak 
diberlakukan lagi, sehingga pemuatan Peraturan Daerah untuk rnengatur pemungutan pajak daerah tidak perlu lagi mengacu pada pendapat tentang hirarki norma hukum.

\section{Daftar Pustaka}

Arifin P. Soeria Atmadja, Mekanisme Pertanggungjawaban Keuangan Negara Suatu Tinjauan Yuridis, Gramedia, Jakarta, 1986

Suparmoko, Keuangan Negara, BPFE, Yogyakarta, 1999

Santoso Brotodihardjo, Pengantar IImu Hukum Pajak, Fresco, Bandung, 1989

Tomo, HS, dkk; Penerimaan Negara Bukan Pajak, YIAPI, Yogyakarta, 2004

Doing Business and Investing in Indonesia, Price Vaterhouse Cooper, 1994

Soedikno Mertokoesoemo, Penemuan Hukum, Liberty, Yogyakarta, 1996

Burhan Ashshofa, Metodologi Penelitian Hukum, Renika Cipla, Jakarta, 1996

Soeryono Sockanto, Metodologi Penelitian
Normatif Rajawali Pets, Jakarta, 1985 Abdurrahrnan, Beberapa Aspek Tentang Pembangunan Hukurn Nasional, Citra Aditya Bakti, Bandurig, 1995

Yudha Bangkit Ardhiwisastra, Penafsiran dan Konstruksi Hukum, Alumni, Bandung, 2000

Kusumadi Pudjosewojo, Pedoman Pelajaran tata Hukum Indonesia, Kasara Baru, Jakarta, 1986

Rochmat Soemitro, Dasar-Dasar Perpajakan Dan Pajak Pendapatan 1944, Eresco, Jakarta-Bandung, 1979

Hans Kelsen, General Theory of Law and State, alih bahasa oleh Somadi berjudul: Teori Negara Murni Dasar-dasar Ilmu Hukum Normative Sebagai IImu Hukum Empirisc-Descreptif, Rindi, Pres, Jakarta, 1995

Laboratorium Hukum Fakultas Hukum Universitas Katholik Parahyangan, Ketrampilan Perancangan Hukum, Citra Aditya Bakti, Bandung, 1997 